\title{
Modified Ovitrap Model and Social Community System Study to Reduce Aedes aegypti Density in Pematang Siantar City
}

\author{
Indra Chahaya $S^{1}$, Novrial ${ }^{2}$ \\ ${ }^{1}$ Public Health Department, University of Sumatera Utara, Indonesia \\ indrachahaya@yahoo.co.id \\ ${ }^{2}$ Architecture Department, University of Sumatera Utara, Indonesia \\ anovrial@yahoo.com.sg
}

\begin{abstract}
Based on data from Health Department of Pematangsiantar, its House Index (HI) was $65.7 \%$ This condition requires attention for the Aedes aegypti mosquito control with the use of egg traps (ovitrap). The ovitrap can be modified by adding abate or natural products such as chili as attractant. The research conducted in East Siantar Districts of Pematang Siantar City with two activities, namely ovitrap modification using abate, chili solution and untreated by using quasi experiment methods. The total sample of 40 houses analyzed by the McNemar test and analyzed the data collection of social studies.

Based on the results of McNemar test toward control group (untreated) showed no association the existence of larva before it is treated with the presence of larvae on week I and II. In each group that used ovitrap abate and chilli solution there was a relationship between the presence of larvae before treatment with the presence of larvae on week I and II with a significant value, $p$ $=0,001$. Based on data from the community social study, mostly the respondents were knowledgeable and nice attitude.

Modification ovitrap using abate and chili as attractants were effectively reduce the presence of mosquito larvae. It is necessary to continue the socialization and the development of other models ovitrap modifications.
\end{abstract}

Keywords - Modified Ovitrap Model, Social Community Study

\section{INTRODUCTION}

Dengue Haemorhagic Fever (DHF) is one of several communicable disease that has been being public health problem in worldwide particularly in developing country.DHF was emerged first time at 1968 in Surabaya, Indonesia. From that time, disease caused by Dengue virus has spreaded to all provincesin Indonesia and being a significant public health problem. DHF, transmitted by Aedes Aegypti is spreading rapidly and potentially cause of death [8].

DHF outbreak still commonly happen in various area in Indonesia. At 1998 there was an outbreak with the number of 720133 people and it was the biggest outbreak with 1.411 deaths or $1.956 \%$ of
Case Fatality rate (CFR). An outbreak in 2004, started from January until April there were 58.861 patients and 669 deaths (CFR:1.14\%). Later in 2005, there were 3.336 patients and 55 deaths es aegypti and associated with environment sanitation by availabilty of breeding place,such as container that filled up by water (bathtub, cans, and the other water reservoir). Those conditions exacerbated by the lack of understanding DHF and also society participation was minimum, seen by poor environmental conditions and facilitate the growth of mosquitos [2]. DHF mitigation have such as dengue virus, host, and affecting environment factors include breeding place. Aedes aegypti likes water reservoirs with clean and clear water which many around the population [7].

The existence of Aedes aegypti larvae in an area is a presence of indicator. In order to eradicate DHF necessary knowledge about Aedes aegypti biologically to control its population. Container Index (CI), House Index (HI), and Breteau Index (BI) are some of indicators measuring the eggs, larvae, pupae and mosquito that connected with DHF case in endemic area [9].

Pematang Siantar city is one of endemic places in North Sumatera Province. Based on Pematang Siantar City's health profile 2012, showed that during the last 5 years, DHF case and mortality was increasing. In 2007, IR 234 per 100.000 population with CFR $2.23 \%$, in 2008 decreased to 195 per 100.000 population with CFR1.44\%, in 2009 increased significantly 245.8 per 100.000 population with CFR $1.13 \%$, in 2010 increased to 254 per 100.000 population with CFR $2.27 \%$, and in 2011 
decreased to 254 per 100.000 with CFR $1.82 \%$. Those conditions showed that there were fluctuation in the case of DHF permanently in Pematang Siantar City. Based on it, IR and CFR Pematang Siantar City has exceeded national indicator, IR must be 50 per 100.000 population and CFR $<1 \%$.

The effort have been made by Pematang Siantar City to control DHF such as precaution and mitigation DHF socialization, abate giving to society by health officer, fogging in appropriate area, and increased epidemilogy surveilance (Community Based Survailance and Hospital Based Surveillance) [3].

To control the larvae do disappearance of breeding place, 3M (drain, close, pile up). Based on the preliminary survey, $3 \mathrm{M}$ could not be done by the society because the water distribution was not enough [6].

There is a way that have been successful to control vector density in some countries are using egg traps (ovitrap). Ovitrap is a tool to attract mosquitoes to lay their eggs. When the eggs developed into adult mosquitoes, they would be trapped in ovitrap, and dead. To maximize ovitrap in vector control, then do some modifications to the ovitrap. Based on Profil Dinas Kesehatan Kota Pematang Siantar (2013) has been found of House Index (HI) 65,7\%.

One of the ways to control Aedes aegyptiwhich is able to decrease dencity of vectors in several contries by using eggs traps (ovitrap). Ovitrap is an equipment to attract mosquitos to spawn in the ovitrap. When the egg grow up to be a mosquito, it will trapped in the ovitrap and causing of death. Ovitrap can be maximalize to control Aedes aegyptiin order to do some modification of ovitrap. Based on research [5], using the ovitrap that has been modification by using abate (temephos) can decrease the number of Container Index (CI) 5,33\% and House Index (HI) 7,74\%. Ovitrap modification can be lethal by adding sort of insecticides on ovitrap, efectivity 45-100 percent.

Ovitrap installation by adding abate has several drawbacks such as society concerns against the negative impacts of chemical contituents, hardly found the abate, and prices are less affordable. Therefore, required replacement of abate with a natural substance and easy-to-get by the society. Attractant is something that can attract mosquitoes to approach breeding place. Attractant can be used to influence behavior, monitoring or decreasing mosquitoes population directly without causing injury to other animals and human does not leave residues on food.

Various types of plants can be used as attractants such as rice straw, red chili, garlic, etc. Red chili is a basic seasoning that always available in every house and can be used as ovitrap attractant because it produces ammonia, $\mathrm{CO}_{2}$, lactic acid, octanol, and fatty acid after going through soaking process for 7 days [10].

The effort to reduce DHF by decreasing mosquitoes density will not work without society participation and health officer. Therefore, commitment and participation of government are very important and needed to be motivation in applying a new inovation to decrease DHF case.

\section{METHODS}

This study implemented in Merdeka Subditrict, Siantar Timur District Pematang Siantar City with 2 actions, modificating ovitrap by using abate, chili solution and untreated by using quasi experiment methods. Observations were made by the larva survey at houses before treated, 1 week and 2 weeks after treated. Then collecting data of social studies.

Data will be analyzed quantitatively and qualitatively. Quantitative data used Mc Nemar test to know significant average difference $(\mu)$ between each samples with degrees of confidence $95 \%$.

\section{RESULT AND DISCUSSION}

Merdeka subdistrict is one of subdistrict in Siantar Timur District, with a total area $0.2300 \mathrm{Km}^{2}$ and had population of 11.849 people. Merdeka Subdistrict have boundaries, north bordered with Asahan Subdistrict, South bordered with Pahlawan Subdistrict, East bordered with Siopat Suhu Subdistrict and West bordered with Pardamuan Subdistrict.

Based on health profile of Merdeka Subdistrict 2013 , the number of residents in the area are 4.335 people, 2.034 men and 2.301 women. The number of households by 625 families.

Based on observation, the existance of larvae in house's containers. 
TABLE I

LARVA SURVEY RESULTS BEFORE OVITRAP MODIFICATION AND SOCIAL COMMUNITY SYSTEM STUDY TO REDUCE AEDES AEGYPTI DENSITY IN PEMATANG Siantar City

\begin{tabular}{|c|c|c|c|}
\hline \multicolumn{2}{|c|}{ Question } & \multicolumn{2}{c|}{ Total } \\
\cline { 3 - 4 } $\begin{array}{c}\text { The } \\
\text { existence of } \\
\text { Larva }\end{array}$ & Present & n & $\%$ \\
\cline { 3 - 4 } & No & 28 & 76.6 \\
\hline \multicolumn{2}{|c|}{ Total } & $\mathbf{1 2 0}$ & $\mathbf{1 0 0}$ \\
\hline
\end{tabular}

Table I shows HI $76.6 \%$ and Larva Free Index (LFI) $23.3 \%$. It shows mosquitoes density in Merdeka Subdistrict still high above HI average number, $95 \%$ to each subdistricts.

TABLE II

FREQUENCY DISTRIBUTION OF RESPONDENTS CHARACTERISTICS IN OVITRAP MODIFIED MODEL AND SOCIAL COMMUNITY SYSTEM STUDY TO REDUCE AEDES AEGYPTI DENSITY IN PEMATANG SIANTAR CITY

\begin{tabular}{|c|c|c|c|c|}
\hline \multirow{2}{*}{ No } & \multirow{2}{*}{\multicolumn{2}{|c|}{ Characteristics of Respondents }} & \multicolumn{2}{|c|}{ Total } \\
\hline & & & $\mathrm{n}$ & $\%$ \\
\hline 1 & Age & $\begin{array}{l}19-30 \\
31-40 \\
41-50 \\
51-60 \\
\geq 60 \\
\text { Total }\end{array}$ & $\begin{array}{l}14 \\
29 \\
33 \\
21 \\
23 \\
\mathbf{1 2 0}\end{array}$ & $\begin{array}{l}11.7 \\
24.1 \\
27.5 \\
17.5 \\
19.2 \\
\mathbf{1 0 0}\end{array}$ \\
\hline 2 & Education & $\begin{array}{l}\text { Primary School } \\
\text { Junior High School } \\
\text { Senior High School } \\
\text { Diploma } \\
\text { Bachelor } \\
\text { Total }\end{array}$ & $\begin{array}{l}7 \\
17 \\
62 \\
11 \\
23 \\
\mathbf{1 2 0} \\
\end{array}$ & $\begin{array}{l}5.8 \\
14.2 \\
51.7 \\
9.2 \\
19.2 \\
\mathbf{1 0 0 . 0}\end{array}$ \\
\hline 3 & Occupation & $\begin{array}{l}\text { Government } \\
\text { employees } \\
\text { Private Employees } \\
\text { Enterpreneur } \\
\text { Unemployee } \\
\text { Retired } \\
\text { Housewife } \\
\text { Student } \\
\text { Etc } \\
\text { Total }\end{array}$ & $\begin{array}{l}21 \\
7 \\
48 \\
8 \\
14 \\
15 \\
3 \\
4 \\
\mathbf{1 2 0}\end{array}$ & $\begin{array}{l}17.5 \\
5.8 \\
40.0 \\
6.7 \\
11.7 \\
12.5 \\
2.5 \\
3.3 \\
\mathbf{1 0 0 . 0}\end{array}$ \\
\hline 4 & Income & $\begin{array}{l}1.000000-2.000 .000 \\
2.000 .000-3.000 .000 \\
\geq 3.000 .000 \\
\text { Total }\end{array}$ & $\begin{array}{l}41 \\
53 \\
26 \\
\mathbf{1 2 0}\end{array}$ & $\begin{array}{l}34.1 \\
44.2 \\
21.7 \\
\mathbf{1 0 0 . 0}\end{array}$ \\
\hline
\end{tabular}

Table II shows respondents characteristics by age, 41-50 years old $(27.5 \%)$; by education level, Senior High School (51.7\%); by occupation (40\%); and average respondent income, Rp.2.000.000 Rp.3.000.000/ month.
TABLE III

FREQUENCY DISTRIBUTION OF RESPONDENT QUESTION IN OVITRAP MODIFIED MODEL AND SOCIAL COMMUNITY SYSTEM STUDY TO REDUCE AEDES AEGYPTI DENSITY IN PEMATANG SiANTAR City

\begin{tabular}{|c|c|c|c|c|}
\hline \multirow{2}{*}{ No } & \multirow{2}{*}{\multicolumn{2}{|c|}{ Qustion }} & \multicolumn{2}{|c|}{ Total } \\
\hline & & & $\mathrm{n}$ & $\%$ \\
\hline 1 & Have family & Ever & 29 & 24.2 \\
\hline & $\begin{array}{l}\text { members suffered } \\
\text { by DHF }\end{array}$ & Never & 91 & 75.8 \\
\hline \multicolumn{3}{|c|}{ Total } & 120 & 100 \\
\hline 2 & Have you ever & Ever & 90 & 75.0 \\
\hline & $\begin{array}{l}\text { heard of DHF } \\
\text { prevention? }\end{array}$ & Never & 30 & 25.0 \\
\hline \multicolumn{3}{|c|}{ Total } & 120 & 100 \\
\hline 3 & $\begin{array}{l}\text { If counseling is } \\
\text { done in your area, }\end{array}$ & I will & 93 & 77.5 \\
\hline & $\begin{array}{l}\text { are you willing to } \\
\text { attend }\end{array}$ & I will not & 27 & 22.5 \\
\hline \multicolumn{3}{|c|}{ Total } & 120 & 100 \\
\hline 4 & Who is the most & Officer & 88 & 73.3 \\
\hline & actively inform & Public Health & 11 & 9.2 \\
\hline & about DHF & Centre & 0 & 0 \\
\hline & prevention & Cadre & 13 & 10.8 \\
\hline & & $\begin{array}{l}\text { Non-governmental } \\
\text { organization }\end{array}$ & & \\
\hline & & Subdistrict Head & 0 & 0 \\
\hline & & Public Figure & 2 & 1.7 \\
\hline & & $\begin{array}{l}\text { Family } \\
\text { Etc }\end{array}$ & 6 & 5.0 \\
\hline \multicolumn{3}{|c|}{ Total } & 120 & 100 \\
\hline
\end{tabular}

Table III shows respondents recognition who had suffered DHF 24.2\%. $75 \%$ to respondents who ever heard DHF prevention. $77.5 \%$ respondents are willing to attend counseling and the most actively inform about DHF prevention is Health Officer, $73.3 \%$.

TABLE IV

FREQUENCY DISTRIBUTION OF DHF PREVENTION INFORMATION RESOURCES IN OVITRAP MODIFIED MODEL AND SOCIAL COMMUNITY SYSTEM STUDY TO REDUCE AEDES AEGYPTI DENSITY IN PEMATANG SIANTAR CITY

\begin{tabular}{|c|c|c|c|c|}
\hline \multirow{2}{*}{ No } & \multicolumn{2}{|c|}{ Question } & \multicolumn{2}{c|}{ Total } \\
\cline { 3 - 5 } & \multicolumn{2}{|c|}{$\begin{array}{c}\mathrm{n} \\
\%\end{array}$} \\
\hline \multirow{2}{*}{1} & If ever, where & HealthOfficer & 49 & 54.4 \\
\cline { 3 - 5 } & did you get the & E-Media & 35 & 38.9 \\
\cline { 3 - 5 } & information & Cadre & 6 & 6.7 \\
\cline { 3 - 5 } & \multicolumn{2}{|c|}{ Total } & $\mathbf{9 0}$ & $\mathbf{1 0 0}$ \\
\hline
\end{tabular}

Table IV shows frequency distribution of information resources of DHF prevention are health officer $54.4 \%$, e-media $38.9 \%$, and cadre $6.7 \%$. 
TABLE V

DISTRIBUTION OF KNOWLEDGE QUESTION RESPONDENT IN OVITRAP MODIFIED MODEL AND SOCIAL COMMUNITY SYSTEM STUDY TO REDUCE AEDES AEGYPTI DENSITY IN PEMATANG SIANTAR CITY

\begin{tabular}{|l|l|l|l|l|}
\hline \multirow{2}{*}{ No } & \multirow{2}{*}{ Question } & Total \\
\cline { 4 - 5 } & Do you know about DHF & I do & 96 & 80 \\
& \multicolumn{2}{|c|}{ Total } & 24 & 20 \\
\hline \multirow{3}{|c|}{ I do not } & 24 & $\mathbf{1 2 0}$ & $\mathbf{1 0 0}$ \\
\hline 2 & Do you know what the & I do & 89 & 74.2 \\
& cause of DHF & I do not & 31 & 25.8 \\
\hline \multicolumn{3}{|c|}{ Total } & $\mathbf{1 2 0}$ & $\mathbf{1 0 0}$ \\
\hline 3. & Do you know that DHF can & I do & 86 & 71.7 \\
& be contagious & I do not & 34 & 28.3 \\
\hline \multicolumn{3}{|c|}{ Total } & $\mathbf{1 2 0}$ & $\mathbf{1 0 0}$ \\
\hline 4 & Do you know where & I do & 81 & 76.5 \\
& mosquitoes lay their eggs & I do not & 39 & 32.5 \\
\hline \multicolumn{3}{|c|}{ Total } & $\mathbf{1 2 0}$ & $\mathbf{1 0 0}$ \\
\hline 5 & Do you know how to & I do & 87 & 72.5 \\
& control Aedes aegypti & I do not & 33 & 27.5 \\
\hline
\end{tabular}

Table $\mathrm{V}$ shows for the second question of knowledge about cause of DHF 74.2\%. Many people believe DHF is not contagious disease $28.3 \%$. From conducted interviews, $76.5 \%$ respondents have known the breeding place of Aedes aegypti and $72.5 \%$ do know how to control Aedes aegypti.

TABLE VI

GROUPING RESPONDENT'S KNOWLEDGE DISTRIBUTION IN OVITRAP MODIFIED MODEL AND SOCIAL COMMUNITY SYSTEM STUDY TO REDUCE AEDES AEGYPTI DENSITY IN PEMATANG SIANTAR CITY

\begin{tabular}{|c|c|c|c|}
\hline \multirow{2}{*}{ No } & \multirow{2}{*}{ Knowledge } & \multicolumn{2}{|c|}{ Total } \\
\hline & & $\mathrm{n}$ & $\%$ \\
\hline 1 & Good & 70 & 58.3 \\
\hline 2 & $\mathrm{Bad}$ & 50 & 41.7 \\
\hline & Total & 120 & 100 \\
\hline
\end{tabular}

After grouping respondent's knowledge, 70 respondents with good knowledge (58.3\%) and 50 respondents with bad knowledge $(41.7 \%)$.

TABLE VII

DISTRIBUTION OF RESPONDENT BEHAVIOR IN OVITRAP MODIFIED MODEL AND SOCIAL COMMUNITY SYSTEM STUDY TO REDUCE AEDES AEGYPTI DENSITY IN PEMATANG SIANTAR CITY

\begin{tabular}{|c|l|l|c|c|}
\hline \multirow{2}{*}{ No } & \multicolumn{2}{|c|}{ Question } & \multicolumn{2}{c|}{ Total } \\
\cline { 4 - 5 } & \multicolumn{2}{|c|}{ Total } & $\mathrm{N}$ & $\%$ \\
\hline \multirow{2}{*}{$\begin{array}{l}\text { Do you agree, it's necessary } \\
\text { to control DHF mosquitos } \\
\text { population }\end{array}$} & I do & 116 & 96.7 \\
\hline \multicolumn{3}{|c|}{ I do not } & 4 & 3.3 \\
\hline 2 & $\begin{array}{l}\text { Do you agree to drain the } \\
\text { tub once a week }\end{array}$ & I do & 111 & 92.5 \\
\hline \multicolumn{2}{|c|}{ Total } & 9 & 7.5 \\
\hline
\end{tabular}

\begin{tabular}{|c|c|c|c|c|}
\hline 3. & $\begin{array}{l}\text { Do you agree to close the } \\
\text { water reservoir }\end{array}$ & $\begin{array}{l}\text { I do } \\
\text { I do not }\end{array}$ & $\begin{array}{l}90 \\
30 \\
\end{array}$ & $\begin{array}{l}75 \\
25 \\
\end{array}$ \\
\hline \multicolumn{3}{|c|}{ Total } & 120 & 100 \\
\hline 4 & $\begin{array}{l}\text { Do you agree to clean the } \\
\text { place that enable to hold } \\
\text { water }\end{array}$ & $\begin{array}{l}\text { I do } \\
\text { I do not }\end{array}$ & $\begin{array}{c}113 \\
7\end{array}$ & $\begin{array}{c}94.2 \\
5.8\end{array}$ \\
\hline \multicolumn{3}{|c|}{ Total } & 120 & 100 \\
\hline 5 & $\begin{array}{l}\text { Do you agree to put abate } \\
\text { on bath tub to reduce DHF } \\
\text { mosquitos }\end{array}$ & $\begin{array}{l}\text { I do } \\
\text { I do not }\end{array}$ & $\begin{array}{c}101 \\
19\end{array}$ & $\begin{array}{l}84.2 \\
15.8\end{array}$ \\
\hline \multicolumn{3}{|c|}{ Total } & 120 & 100 \\
\hline 6 & $\begin{array}{l}\text { Do you agree to use chili as } \\
\text { abate replacement }\end{array}$ & $\begin{array}{l}\text { I do } \\
\text { I do not }\end{array}$ & $\begin{array}{c}104 \\
16\end{array}$ & $\begin{array}{l}86.7 \\
13.3\end{array}$ \\
\hline \multicolumn{3}{|c|}{$\begin{array}{c}\text { Total } \\
\end{array}$} & 120 & 100 \\
\hline 7 & $\begin{array}{l}\text { Do you agree to survey the } \\
\text { larvae once a week }\end{array}$ & $\begin{array}{l}\text { I do } \\
\text { I do not }\end{array}$ & $\begin{array}{c}102 \\
18\end{array}$ & $\begin{array}{l}85 \\
15 \\
\end{array}$ \\
\hline \multicolumn{3}{|c|}{ Total } & 120 & 100 \\
\hline
\end{tabular}

Table VII shows 4 respondents (3.3\%) disagree to control mosquitos population and 116 respondents (96.7\%) agree to do.92.5\% agree to drain the tub once a week and $75 \%$ agree to close the water reservoir. $84.2 \%$ of repondents agree to put abate in bath tub to reduce DHF mosquitoes.

TABLE VIII

DISTRIBUTION OF GROUPING REPONDENT'S BEHAVIOR IN OVITRAP MODIFIED MODEL AND SOCIAL COMMUNITY SYSTEM STUDY TO REDUCE AEDES AEGYPTI DENSITY IN PEMATANG SiANTAR CITY

\begin{tabular}{|c|c|c|c|}
\hline \multirow{2}{*}{ No } & \multirow{2}{*}{ Behavior } & \multicolumn{2}{|c|}{ Total } \\
\hline & & $\mathrm{n}$ & $\%$ \\
\hline 1 & Good & 99 & 82.5 \\
\hline 2 & Bad & 21 & 17.5 \\
\hline & Total & 120 & 100 \\
\hline
\end{tabular}

After grouping respondent's behavior, 99 respondent $(75 \%)$ have good behavior and 21 respondent $(17.5 \%)$ have a bad behavior.

TABLE IX

DISTRIBUTION OF TREATMENT GROUPING AT 1ST WEEK OF OVITRAP MODIFIED MODEL AND SOCIAL COMMUNITY SYSTEM STUDY TO REDUCE AEDES AEGYPTI DENSITY IN PEMATANG SIANTAR CiTY

\begin{tabular}{|c|c|c|c|c|c|}
\hline \multirow[t]{2}{*}{ No } & \multirow{2}{*}{$\begin{array}{l}\text { Existence of } \\
\text { Larva in } \\
\text { Initial } \\
\text { Condition }\end{array}$} & \multicolumn{2}{|c|}{$\begin{array}{c}\text { Existence of } \\
\text { Larva at 1st week }\end{array}$} & \multirow[t]{2}{*}{ Total } & \multirow[t]{2}{*}{$\mathbf{p}$} \\
\hline & & Present & No & & \\
\hline \multicolumn{6}{|c|}{ Without treatment } \\
\hline \multirow[t]{2}{*}{1} & Present & 9 & 6 & 15 & \multirow{3}{*}{$\mathbf{0 . 5 0 8}$} \\
\hline & No & 3 & 22 & 25 & \\
\hline & Total & 12 & 28 & 40 & \\
\hline \multicolumn{6}{|c|}{ Ovitrap with Abate Attractant } \\
\hline 2 & Present & 5 & 11 & 16 & \multirow{3}{*}{0.00} \\
\hline & No & 0 & 24 & 24 & \\
\hline & Total & 5 & 35 & 40 & \\
\hline \multicolumn{6}{|c|}{ Ovitrap with Chili Attractant } \\
\hline 3 & Present & 11 & 27 & 38 & \multirow{3}{*}{0.001} \\
\hline & No & 1 & 1 & 2 & \\
\hline & Total & 12 & 28 & 40 & \\
\hline
\end{tabular}


Table IX shows that there is no significant association between the existence of larva in initial condition with existence of larva in 1st week, $p=$ 0.0508. Ovitrap with abate attractant shows a significant association between the existence of larva in initial condition with existence of larva at 1st week, $p=0.001$, so does the ovitrap with chili attractant, $p=0.001$.

TABLE X

DISTRIBUTION OF TREATMENT GROUPING AT 2ND WEEK OF OVITRAP MODIFIED MODEL AND SOCIAL COMMUNITY SYSTEM STUDY TO REDUCE AEDES AEGYPTI DENSITY IN PEMATANG SIANTAR CITY

\begin{tabular}{|c|c|c|c|c|c|}
\hline \multirow[t]{2}{*}{ No } & \multirow{2}{*}{$\begin{array}{l}\text { Existence of } \\
\text { Larva in } \\
\text { Initial } \\
\text { Condition }\end{array}$} & \multicolumn{2}{|c|}{$\begin{array}{c}\text { Existence of } \\
\text { Larva at } 2 \mathrm{nd} \\
\text { week }\end{array}$} & \multirow[t]{2}{*}{ Total } & \multirow[t]{2}{*}{$\mathbf{p}$} \\
\hline & & Present & $\mathrm{No}$ & & \\
\hline \multicolumn{6}{|c|}{ Without treatment } \\
\hline 1 & Present & 7 & 8 & 15 & \multirow{3}{*}{0.227} \\
\hline & No & 3 & 22 & 25 & \\
\hline & Total & 10 & 30 & 40 & \\
\hline \multicolumn{6}{|c|}{ Ovitrap with Abate Attractant } \\
\hline 2 & Present & 2 & 14 & 16 & \multirow{3}{*}{0.001} \\
\hline & No & 0 & 24 & 24 & \\
\hline & Total & 2 & 38 & 40 & \\
\hline \multicolumn{6}{|c|}{ Ovitrap with Chili Attractant } \\
\hline \multicolumn{5}{|c|}{\begin{tabular}{|c|c|c|}
3 & Present & 5
\end{tabular}} & \multirow{3}{*}{0.001} \\
\hline & No & 0 & 2 & 2 & \\
\hline & Total & 5 & 35 & 40 & \\
\hline
\end{tabular}

Table $\mathrm{X}$ shows that there is no difference between the existence of larva in initial condition with existence of larva in 2nd week, $p=0.227$. It assumed for this without treatment group. There is a significant association between the existence of larva in initial condition with existence of larva at $1 \mathrm{st}$ week, $p=0.001$ and so does the ovitrap with chili attractant, $\mathrm{p}=0.001$.

From conducted interviews with community shows the participation of health officer, cadre, subdistrict officer and community which still low in preventing DHF transmission. It is based on without treatment data with House Index (HI) 76.6\%. based on McNemar test, the effective use of ovitrap by increasing Larva Free Index (LFI) to be $85.5 \%$. This is indicated by each significant value, $p=0.001$ for using abate and chili as attractant in ovitrap.

\section{CONCLUSION}

Interviews result showed that the participation of health officer, cadre, subdistrict officer and community were still low in preventing DHF transmission. It is based on data of untreated group with House Index (HI) 76.6\%. Based on McNemar test, the effective use of ovitrap is by increasing Larva Free Index (LFI) to be $85,5 \%$. This is indicated by each significant value, $p=0.001$ for using abate and chili as attractant in ovitrap.

Suggestion for this program is an approach to community, religious leaders, and public figure to decrease the number of DHF case through reduction of mosquito density and the next research about the using of attractant to increase the Larva Free Index.

\section{ACKNOWLEDGEMENT}

The authors wish to thank to all staff members at Health Department in Pematang Siantar City. We would also like to thank them for their valuable comments and suggestions. This work was supported by a research institutions under North Sumatera University, Medan, Indonesia

\section{REFERENCE}

[1] Achmadi, Umar Fahmi. 2011. Dasar - Dasar Penyakit Berbasis Lingkungan. Jakarta: Rajawali Pers

[2] Anies. 2006. Manajeme Berbasis Lingkungan Solusi Mencegah dan Menanggulangi Penyakit Menular. Jakarta: Gramedia

[3] Dinas Kesehatan Pematang Siantar. 2012. Profil Kesehatan Kota Pematang Siantar.Pematang Siantar

[4] Hasan, Iqbal. 2002. Pokok-Pokok Materi Metodologi Penelitian dan Aplikasinya. Cetakan Pertama. Jakarta: Ghalia Indonesia

[5] Hasyimi, Sukirno. 2004. Pengamatan Tempat Perindukan Aedes aegypti pada Tempat Penampungan Air RumahTangga pada Masyarakat Pengguna Air Olahan. Health Ecological Journal April 2004, Vol.3; 37 42

[6] Hatang, IT. 2010. Analisis Perbandingan Pelaksanaan Pengelolaan Program Pemberantasan Nyamuk Demam Berdarah Dengue antara Puskesmas " $X$ ” dan Puskesmas " $Y$ ” Kota Bogor Tahun 2010. Thesis. Jakarta: Public Health Faculty, Universitas Indonesia

[7] Hendri, J Nusa.,R.Prasetyowati. 2010. Tempat Perkembangbiakan Nyamuk Aedes sp di Pasar Wisata Pangandaran. Aspirator Vol.2 No.1 Tahun 2010: 23-31

[8] Kementrian Kesehatan Republik Indonesia. 2012. Buletin Jendela Epidemiologi Pusat Data dan Surveilans Epidemiologi. Jakarta

[9] Kesetyaningsih, T.W., Sundari, S. 2006. Perbedaan antara Indeks yang Melibatkan Pemeriksaan Sumur dengan yang Tidak Melibatkan Pemeriksaan Sumur pada Survey Vektor Dengue di Dusun Pepe Bentul Yogyakarta. Thesis. Yogyakarta: Medical Faculty of Muhammadiyah University Yogyakarta

[10] Sari, P Martini.,Ginanjar P. 2012. Hubungan Kepadatan Jentik Aedes sp dan Praktik PSN dengan Kejadian DBD di Sekolah Tingkat Dasar di Kota Semarang. Public Health Journal Vol.1 No.2 Tahun 2012. Halaman 413-422

[11] Sitio, A. 2008 Hubungan Perilaku tentang Pemberantasan Nyamuk dan Kebiasaan Keluarga dengan Kejadian Demam Berdarah Dengue di Kecamatan Medan Perjuangan Kota Medan Tahun 2008. Thesis. Semarang: Postgraduate program of Diponegoro University

[12] Sukowati, S. 2010. Masalah Vektor Demam Berdarah Dengue dan Pengendaliannya di Indonesia. Jendela Epidemiologi Bulletin Vol.2 Agustus 2010 
[13] World Health Organization, 2005. Panduan Lengkap Pencegahan dan Pengendalian Dengue dan Demam Berdarah pada Anak Jakarta. Media Medika Muda Journal. Semarang: Medical Faculty of Diponegoro University

[14] Yudhastuti, R., Vidiyani, A. 2005. Hubungan Kondisi Lingkungan Kontainer, dan Perilaku Masyarakat dengan Keberadaan Jentik Nyamuk Aedes aegypti di Daerah Endemis Demam Berdarah Dengue Surabaya. Environmental Health Journal Vol.1, 171 No/2, January 2005

[15] ZeicherBC.,Perich MJ. Laboratory Testing of Lethal Ovitrap for Aedesaegypti. Medical and Veterinary Entomology 1999, 13 :234-238 